\title{
LIBERDADE DRAMÁTICA: ÉTICA E LITERATURA NA ESCRITA DE SARTRE
}

\author{
Priscila Rossinetti Rufinoni* \\ pitirufinoni@yahoo.com.br
}

RESUMO Este artigo pretende investigar, nos romances de Jean-Paul Sartre, a tessitura entre forma literária, investigação filosófica e escolha ética implicada no trabalho do escritor.

Palavras-chave Escolha ética; Forma literária; Romance.

ABSTRACT This paper intends to investigate, in the novels by JeanPaul Sartre, the relationship between literary form, philosophical investigation and ethical choice implied in the work of the writer.

Keywords Ethical choice; Literary form; Novel.

\section{A náusea e a liberdade}

"De tarde", anota simplesmente a personagem Roquentin, ao assegurar-se de que o dono do Café Mably - assim como todo o resto do mundo afundado na neblina de um inominável absurdo no dia anterior - estava do mesmo jeito: não havia nenhum morto no andar superior do café, apenas uma corriqueira "gripe muito forte" afastara o Sr. Fasquelle de seu cotidiano. "De tarde", num sábado, Roquentin vai ao Museu de Bouville; vai ver, porque é tão importante quanto todo o resto, o retrato de um certo Olivier Blévigne. Já tem em mãos,

* Doutora em Filosofia - USP. Professora substituta de Estética e Teoria da Arte na FAV - Universidade Federal de Goiás. Artigo recebido em agosto de 2007 e aprovado em março de 2008. 
pois a conhece há muito tempo, todos os dados sobre essa personagem retratada, consultou há dois anos o Pequeno dicionário dos grandes homens de Bouville: Blévigne estudara em Paris, casara-se, tivera um filho morto prematuramente, fora deputado.

Na sala em que a pintura está instalada, uma coleção de outros retratos já conhecidos por Roquentin está enfileirada nas paredes. O negociante Pacôme, belo homem de 50 anos, sem nenhuma falha; seu filho Jean Pacôme, com aquele olhar cinzento que "nunca a menor dúvida cruzara"; o velho avô, sábio e plácido, "cor de azinhavre". Cada uma destas figuras, cujas histórias bem alinhavadas Roquentin conhece, pronunciam um julgamento; julgamento unilateral de olhar pintado, reconhece o narrador, pois "o que eu podia pensar a seu respeito não o atingia; não passava de psicologia como a que se faz nos romances. Mas seu julgamento me trespassava como um gládio e questionava até meu direito de existir". ${ }^{1}$

Não há retoques possíveis para essas figuras, se me distancio da "coisa" material, o objeto-tela, se nela penetro, chego à imagem do homem retratado, um homem em imagem que não está submetido às variações contingentes; nem mesmo depende da materialidade do suporte, da tinta, devolve-nos apenas, eternamente, o que o pintor fixou. Também os títulos, as referências encontradas no Pequeno dicionário, as historietas, compondo uma trama de ligações entre os retratados, revestem-se de uma necessidade, já que são tecidos sobre a própria história da cidade, história daquelas casas, daquelas ruas, daquela grande igreja, dando a todas as coisas aparentemente sem sentido um liame narrativo, uma causalidade necessária. Sob o olhar dessa verdade pura, pétrea como a igreja mais cara da França: "minha existência começava a me espantar seriamente. Não seria eu uma simples aparência?". ${ }^{2}$

Essas figuras despertam a consciência perturbadora da "existência" do narrador, pois elas "não existem", nem mesmo "existiram" no mesmo "passado" contingente de que Roquentin fez parte. São homens colocados em imagem, atendendo à distinção que Sartre faz em $A$ imaginação, nada mantendo de reverberações, de simulacros, de uma percepção, mesmo que atenuada, do "homem real". Como a folha de papel que o escritor "sabe" estar em sua mesa, embora não a veja, essa identidade "em essência" e não "em existência", transforma as pessoas retratadas; cada uma delas "não existe de fato, existe em imagem". 
É o baralhamento entre os dois modos de ser da coisa, espécie de "metafísica ingênua" representada na familiaridade burguesa que um casal mantém com os retratados em confronto ao estranhamento de Roquentin, que tende a transformar os quadros em "simulacros" das coisas, "ídolos". A senhora e o senhor que dividem a sala com o narrador durante sua visita ao museu agem como se também pertencessem à necessidade imanente daqueles outros "homens"; reconhecem-lhes como parentes distantes; vivem naquele mesmo mundo de certezas, de pequenos direitos.

Essa imagem-simulacro subsidiária de uma percepção real é inferior à existência, uma vaga miragem de percepções extintas, sempre, desta que é a perspectiva da filosofia clássica, defeituosa, imperfeita. A imperfeição da Imaginação, do ponto de vista da filosofia clássica, é derivada da pressuposta "identidade de natureza entre imagem e sensação". ${ }^{3}$

Em A imaginação, Sartre, apoiado na fenomenologia de Husserl, separa imagem de sensação. A imaginação não é subsidiária (uma miragem, um enfraquecimento) de uma percepção. Não há analogia entre imaginar e perceber. A consciência imaginante é consciência de um objeto que "não existe"; uma modalidade própria em nada subordinada às sensações. Pelo contrário: a função imaginante da consciência precisa negar a realidade; colocando entre parênteses a fatalidade do real, a existência, é que a consciência "põe" objetos em imagem. A consciência pode, então, construir um objeto à margem da fatalidade das coisas: esses homens pintados, bidimensionais, salvos daquele afundamento na neblina absurda da contingência, opõem-se ostensivamente à frágil existência de Roquentin.

Para, na consciência, manter a separação entre imagem e percepção, Sartre retoma Husserl: uma gravura de Dürer é primeiro percebida passivamente como "objeto-coisa" - papel, linhas pretas sobre ele -, mas depois, por uma intencionalidade da consciência, percebemos sua obra como "objetoimagem" - um cavaleiro, a morte etc. O ato de intencionalidade distingue percepção e imagem; distinção intrínseca, já que não pertence à matéria, mas às intenções:

Assim toda ficção é uma síntese ativa, um produto de nossa livre espontaneidade; toda percepção, ao contrário, é uma síntese puramente passiva. A diferença entre imagem, ficção e percepção procederia, pois, da estrutura profunda das sínteses intencionais. ${ }^{4}$ 
Roquentin, embora ainda não se tenha completado a revelação, já sabe dessa irrealidade fictícia dada pelos "homens-imagem" da galeria de Bouville. Talvez até tenha uma certa inveja daquele passado estável que nem todos os seus cartões postais, fotografias ou relatos de "aventuras" chegam a traçar. Ao contrário, o passado de Roquentin desmaterializa-se, parece escapar-lhe assim que se põe em palavras, assim que se ousa traçar, entre aqueles fragmentos factuais fechados em si mesmos, relações ou nexos causais. Da mesma forma que as linhas traçadas no papel, as palavras sobre o Marquês de Rollebon, a personagem que Roquentin pesquisa para escrever uma biografia, assim que escritas, já deixam de pertencer-lhe. Não há nada por trás dos fenômenos; não há um ser que se desdobra no tempo. As coisas são fenômenos em si, portanto o passado não está irremediavelmente ligado ao presente, como aquele "passado heróico" dos grandes homens de Bouville:

Aliás, muitas vezes estes próprios fragmentos desaparecem: só restam palavras; poderia ainda contar as histórias, contá-las muito bem (em matéria de anedota, ninguém me ganha, a não ser os oficiais da marinha e os profissionais), mas já não passam de carcaças. Referem-se a um sujeito que fez isso e aquilo, mas não sou eu, não tenho nada em comum com eles. ${ }^{5}$

O passado é um amontoado amorfo. Aranjuez, Canterbury, as cidades que visitara, quando quer citá-las, só encontra a reverberação fictícia de uma palavra-imagem:

Às vezes, em meus relatos, ocorre que pronuncie esses nomes bonitos que se lêem nos atlas: Aranjuez ou Canterbury. Provocam em mim imagens totalmente novas como as que formam, a partir de suas leituras, pessoas que nunca viajaram: construo sonhos a partir de palavras, isso é tudo. ${ }^{6}$

Para ser, o passado precisa deixar de ter existido, precisa transformarse em "aventura", precisa ser em imagem como exemplificam os homens de Bouville, cujo passado possui essência em função da "aventura" da cidade que construíram. Por essa construção, por terem dado à cidade seus bens atuais, 0 museu lhes reserva a imortalidade naquela sala de retratos. A cidade pode ser colocada "por trás", ali onde está o nada, dessas personagens, dando-lhes um passado estável porque finalizado na cidade atual.

Há, neste momento do romance, uma tensão entre a existência que Roquentin vem descobrindo como contingência absurda e a essência, a 
necessidade. Roquentin é um escritor, está na cidade para pesquisar sobre o Marquês de Rollebon, bizarra personagem do século XVIII, cuja vida é matéria de seu livro; embora não se dedique ostensivamente à redação deste livro, é por esse trabalho que se instalou em Bouville e que segue todos os dias até a biblioteca: estudar a vida de Rollebon constitui-se como um dos poucos sentidos da vida de Roquentin. Mas escrever sobre Rollebon, a partir daquelas cartas que um dia roubara (não ele, Roquentin, mas um sujeito qualquer desse passado inexistente) dos Museus de Moscou? Escrever sobre aquele homem contingente, sem qualquer necessidade, cuja ligação com aquelas folhas amareladas - suas cartas - não era senão um outro acaso? Escrever sobre uma vida que, se tivera alguma "necessidade", teria de ser fictícia, tentando costurar os fenômenos uns aos outros como se houvesse uma determinação irremediável a uni-los?

E, para manter vivo, ainda que por um átimo, o Marquês a quem emprestara sua existência, Roquentin evoca a sua descrição pela Sra. de Genlis, evoca seu "retrato". Mas é tarde demais, nem mesmo a materialidade real das cartas amareladas pode devolver, por meio das relações causais que as fizeram aparecer ali, naquele momento, quaisquer dos fatos anteriores: que tivessem sido escritas por alguém, que houvessem sido roubadas por um outro escritor interessado em seus conteúdos, nada reduziria a existência sem sentido de coisa daqueles papéis. O passado não existe, as cartas apenas são o que parecem ser: folhas amarelas. Aquela espécie de sobrevida que Roquentin dera ao Marquês em sua consciência esvanecia-se: "seu rosto me apareceu docilmente, seu nariz pontiagudo, suas faces azuis, seu sorriso [...]. Só que já não era senão uma imagem em mim, uma ficção".

O Marquês é apenas “imagem em mim”, é em imagem, Roquentin não sente mais seu peso, sua existência. Toda a complicada história que buscara desvendar - a participação ou não de Rollebon em determinadas situações políticas, seu testamento, o assassinato de seu sobrinho -, nada disso podia ser escrito. O Marquês retornava ao vazio que era o passado.

O retrato de Olivier Blévigne, ao qual Roquentin originalmente se destina quando vai ao museu, é uma pintura que lhe chama a atenção, por um erro de perspectiva, talvez? Algo de cômico, de mal arranjado conferia à personagem da tela uma "instabilidade". Roquentin se dá conta de que o estranhamento devese ao estratagema do pintor para disfarçar a estatura ridícula do deputado:

Soube a verdade folheando o Satirique Bouvillois. O número de 6 de novembro de 1905 era inteiramente dedicado a Blévigne. Representavam-no na capa, minúsculo 
agarrado à juba de Combes, com a legenda: O Piolho do Leão. E já na primeira página tudo se explicava: Olivier Blévigne media um metro e cinqüenta e três. ${ }^{7}$

Um jornal devidamente datado: a intromissão, no retrato essencial, do homem contingente, do homem histórico de "um metro e cinqüenta e três!", eis a falta de estabilidade da imagem, seu ridículo. Quando Roquentin principia a distinção entre "existir" e "ser", o Marquês de Rollebon, instável entre ser real e ser em imagem, não pode mais constituir-se como objeto de um livro. Pois, podendo a todo o momento romper a ficção pura, desmascarar a negação da fatalidade do real por um qualquer resto de "contingência", de "existência", como ocorrera com o retrato de Olivier Blévigne, o Marquês afunda-se no nada que é o passado amorfo, sem finalidade.

A conciliação entre o homem contingente e a necessidade vem, para Roquentin, quando este, como sempre fazia, ouve um velho blues na vitrola de um café, mas ouve-o e só então entende por que a música parecia vencer a náusea: na elaboração musical, em seu ser, há a necessidade. A música não existe, existem o disco, a velha vitrola, o ar em que vibram os sons, o compositor, a cantora; mas a música, formada por aquela negação do real que a modalidade imaginante da consciência opera, é um "não-existente", é essencial. A música é. E, nesse absoluto que é a música, o compositor e a cantora que emprestaram sua existência a essa essência, como aqueles homens-imagem do museu, podem ser salvos do absurdo do nada. Se existiram ou existem, na música, os fatos de suas vidas aparecem enfeixados, convergindo para aquela criação, e o passado, tendo por detrás a música, pode ser atualizado, pode fazer sentido por esse "milagre" sempre atual que é a sua canção. Ao tornar atual este "nãoexistente", ao presentificar tudo o que antes não era senão o nada como o passado, Roquentin pode suprimir a atualidade incômoda e inútil do real. E, nessa visada salvacionista, recua ante aquela perspectiva limítrofe em que a existência inenarrável, inominável e indistinta se abria para as ações livres. Por que não, se isto permitiria que, pelo menos na consciência de outros, a vida tivesse um sentido, por que não escrever um livro? Mas um livro em que qualquer perigo da intromissão da contingência estivesse afastado, portanto não o velho projeto da vida do Marquês. Essa tranqüilidade post mortem que Roquentin almeja assenta-se, mesmo que palidamente, no espaço vazio antes ocupado pela certeza metafísica ou religiosa.

Não é explícito, mas a concepção salvacionista de literatura do narrador avizinha-se perigosamente daquela tautologia art pour l'art muito bem 
analisada por Sartre em $O$ que é literatura?. Primeiramente, Roquentin, fazendo equivaler, em sua necessidade e causalidade intencionalmente organizada e fechada em si mesma, toda modalidade de criação artística - a pintura, a música no café, seu próprio livro de aventura -, não está atento à especificidade do ato literário em prosa; não o assume como ação, mas antes como um recuo ante a liberdade plena que a descoberta da total contingência lhe descortinara. Essa abstração de que é vítima Roquentin - a Arte -, assim como todas as demais abstrações - o Homem, a Humanidade -, não são senão formas de mascarar a necessidade do escritor de fazer escolhas, de situar-se em sua época; transpassada pela historicidade, a obra de um autor é ação, é liberdade e visa à liberdade do leitor. A literatura não é a grande galeria dos mortos, daqueles que já "pintaram a si mesmos por inteiro"; o longo cemitério plácido, ao qual os epitáfios dão sentido, tornando sustentável um passado absolutamente, irremediavelmente contingente e amorfo; não é o refúgio descarnado em que tudo o que era humano, histórico, todas as afeições humanas são transformadas, passam "à categoria de afeições exemplares, em suma, de valores". Abstrações, do mesmo tipo daquelas que Roquentin condena no Autodidata quando lhe pergunta: se ama os homens, o que diz o casal ao lado? Qual a cor do cabelo da moça? Que tipo de velho é aquele caixeiro viajante? Interessa-se por este indivíduo, aquele outro, o outro ainda, ama-os, a todos, insiste Roquentin, ou ama as vagas abstrações "literárias": a Mocidade, o Amor, a Maturidade? Neste capítulo do livro, Roquentin sente-se próximo da máxima "tudo pode acontecer"; poderia furar com a faca da sobremesa o olho daquele medíocre leitor de humanistas mortos; um ato supérfluo a que não dava vazão pelo simples motivo de sua gratuidade: "já há coisas suficientes sem isso".

Portanto é paradoxal que uma tendência à abstração possa ser percebida na idéia de salvação daquela "vida" sem sentido que Roquentin vislumbra na música. Para o seu pensamento talvez possamos aplicar a ironia sartreana aos críticos literários: "os mortos lá estão: nada mais fizeram senão escrever, há muito estão lavados do pecado de viver, e, de resto, só conhecemos suas vidas através de outros livros que outros mortos escreveram a seu respeito". ${ }^{8}$ E, se o mundo contingente é suspenso para que em seu lugar a consciência possa "pôr" a ficção como uma alternativa à liberdade irremediável do real, podemos também simplesmente fechar um livro e exclamar "com a alma tranqüila: "Tudo isso não passa de literatura", 9 " 
Sartre, tornando claro o componente abstratizante da generalização "Arte", pergunta pelas especificidades intrínsecas à literatura que a distinguem da pintura, da música; qualidades de uma determinada modalidade artística, com suas nuances técnicas próprias, diversa daquela generalidade oca do termo "Arte". E vai além, em uma de suas teses que sempre gerou polêmica e que pode até ser desmentida pela própria tessitura de seus textos literários: Sartre separa radicalmente prosa e poesia. Enquanto a palavra, para o poeta, é uma palavra-coisa, a língua percebida por seu avesso, como signos, aproximando-se daquele "objeto-imagem" dado na pintura, para o prosador, a palavra é apenas um significante imediatamente remissível às coisas mesmas; as palavras em uma página de romance não são, como a imagem na tela, como o próprio morfema com seus aspectos formais e sonoros na poesia. Se há a materialidade do livro, "as palavras são transparentes e o olhar as atravessa" 10 em direção ao referente. Pois a linguagem prosaica está sempre em situação, sempre é dada no contexto de um todo, de uma perspectiva humana; nunca, como a palavra poética, do lado de fora, do avesso, por uma espécie de olhar divino. As três perguntas formuladas por Sartre para entender sem preconceitos em sua especificidade a prosa literária - $\mathrm{O}$ que é escrever? Por que se escreve? Para quem se escreve? - vão gradativamente apontando para uma situação histórica do escritor.

Criar um romance também é negar o real por meio daquela consciência imaginante que põe o inexistente essencial; mas a palavra, com seu poder de remissão, sempre está situada, só pode visar o universal pelo particular, em uma semi-obscuridade. O momento histórico, a absurda contingência que assombra Roquentin, para quem nele está imerso não tem seqüência, não tem finalidade, objetividade; o escritor, como homem histórico, é uma consciência que só pode estar em perspectiva, portanto em todo ato está em jogo o Bem e o Mal: nenhuma pretensa autonomia da literatura, nenhuma essencialidade supera a história que atravessa o ato literário; o momento histórico não é algo externo, uma contingência que devemos afastar da universalidade do literário, pois o escritor, como homem livre escrevendo para leitores livres, só pode ter uma perspectiva historicamente dada. Contingência e essencialidade, pelo menos na literatura, não se anulam, não se excluem, vivem em uma tensão dialética.

$\mathrm{Na}$ literatura, se a tese em si mesma pode ser criticada como uma coerção à liberdade artística, não podemos também pensar a prosa literária como 
totalmente desprovida de significação. Blanchot enuncia esta contradição que toda as teorias da "pureza" literária carregam: "Uma obra literária deveria obrigatoriamente significar alguma coisa? Por que seria preciso que ela só a significasse por acaso ou por sorte? E já que nós, leitores, seremos fatalmente associados a certa visão de mundo, o honesto não seria nos apresentá-la claramente, e não à traição, ou seja, jogar o jogo franco conosco o que é próprio ou defeito das obras de tese?"11 Sartre descreve com sutil ironia a guinada de alguns críticos da significação explícita de uma obra para os sentidos ocultos, psicológicos, perpassados pelas vicissitudes do homem-escritor: Rousseau é interessante por ter abandonado seus filhos, Nerval por sua loucura. Na obra interessa o retrato acabado de um passado morto, de emoções humanas: "os raciocínios tiram das lágrimas o que elas têm de obsceno; as lágrimas, revelando sua origem passional, tiram do raciocínio o que ele tem de agressivo". ${ }^{12}$ Todas as obras acabam por se equivaler, já que seus sentidos estão sempre além, ou "atrás", do raciocínio. Fugindo do que significam para um além de "pureza", as obras são "curtidas, refinadas, quimicamente tratadas" para tornaremse inofensivas subjetividades objetivadas, razões que disfarçam loucuras, pensamentos que escondem o "homem". Livros tranqüilamente devolvidos à estante e ao imaginário do inexistente absolutamente negativo.

$A$ náusea é um romance, não deixa de ser quase uma metalinguagem pesquisar a filosofia de Sartre na voz de uma de suas personagens; não deixa de ser um exercício formalista. Também podemos abordá-lo pela perspectiva teórica, por sua tese, mas o romance não é apenas a descrição objetivada em uma figura de uma teoria que se desvenda, que se completa: A náusea, no dizer de Blanchot, é, antes, um romance de revelação. Revelação da contingência para a personagem Roquentin; revelação da experiência com as palavras, ao aproximar-se do inominável, do inenarrável, para o Autor. Uma obra que fala da contingência, mas que, como obra de arte, negar-se-ia a habitá-la? Contingência, liberdade e necessidade, "transmutação contínua do irreal em real e do real em irreal", ${ }^{13}$ são não só o assunto do texto, mas também os procedimentos que perpassam a própria gênese do livro.

Se a literatura sob o peso da historicidade pode encastelar-se em uma "aristocracia do espírito", também a filosofia o faz, fugindo para os "sistemas" abstratos; entretanto, se os escritores se engajarem, assumirem a consciência 
da escolha irremediável da condição humana, condição do ser livre e ao mesmo tempo historicamente situado, literatura e filosofia encontram-se:

Pode acontecer que a filosofia, renunciando a se sair bem como sistema, rejeitando conceitos prévios e construções implícitas, se volte para as coisas, para o mundo e os homens e procure retomá-los em seu sentido não-obscurecido. Essa filosofia descreve o que aparece, isto é, o que realmente se mostra próximo no que aparece, ela se interessa por situações reais, nelas mergulha para chegar ao nível de profundidade em que acontece o drama da existência. ${ }^{14}$

\section{O drama da liberdade}

Tomado pelo espírito de "bom senso" da Terceira República, luz acadêmica que banhava o saguão, Mathieu não via os quadros em exposição: "via tudo o que era real, tudo o que essa luz clássica podia clarear, os muros, as telas nas suas molduras, as cores pastosas sobre as telas. Não os quadros. Os quadros tinham-se apagado e parecia monstruoso que no fundo desse banho de bom senso tivesse havido gente capaz de pintar, de deitar sobre a tela objetos inexistentes". ${ }^{15}$ Sob uma visada burguesa, aquela consciência própria da Terceira República, as telas não eram senão objetos sem fundo como quaisquer outros; Mathieu, nesse momento, sentia-se incapaz de escapar à existência contingente daquelas telas emolduradas, daquelas "manchas nos muros" dos salões. Para entendê-las como quadros, entendê-las em imagem, em sua essência de objetos inexistentes que, para serem, negam o real, seria preciso pôr entre parênteses a fatalidade contingente e chegar à essência, ao estado de coisa, de em-si próprio às imagens. Diante dos quadros, a consciência descobre-se vazia de conteúdos, pois não há juízos prontos, não há nada que não seja contingente e relativo: os mesmos quadros, outrora belos, agora são objetos. Mathieu descobre-se culpado, responsável, descobre-se como escolha, como ato. Aceitar ou negar a essência dos quadros, escolher entre visá-los como "molduras, telas, cores pastosas", ou como imagem, não é algo dado, uma percepção, mas movimento, intenção: "os quadros não pegam a gente, pensava afastado, eles se apresentam. 'Sua existência depende de nós. Diante deles sou livre. Livre demais'. Isso criava uma responsabilidade suplementar e ele se sentia culpado". ${ }^{16}$ 
A relação da personagem Mathieu com as obras de arte é uma relação que desnuda as operações de intencionalidade da consciência. Se "na semana anterior" Mathieu achara o retrato belo, "agora, ele parecia seco. Aliás, não via o quadro"; essa realidade movediça, passível de várias significações, põe, na nadificação do objeto-imagem que a personagem encontrara anteriormente no museu e já não via nessa outra visita, o homem como um para-si, uma consciência ativa, na qual tudo está em jogo. Não há uma obra a ser percebida passivamente por um aparelho perceptivo, mas toda uma operação de negação pela consciência imaginante na intenção de perceber aquelas telas emolduradas, aqueles objetos, como objetos-imagem. Essa condição de ser cujo ser está em permanente questão, de pura intencionalidade, é, para Mathieu, uma condição angustiante, uma liberdade que escapa aos seus "projetos de liberdade" tão longamente cultivados; uma liberdade que lhe é demais.

A angústia intensifica-se por dar-se diante de objetos especiais, objetos que haviam tido a capacidade de comovê-lo: "da primeira vez que vira aquela carne obscena e terrível, Mathieu se comovera. Mas estava só. Agora, tinha a seu lado um corpinho rancoroso e Mathieu sentia vergonha de si próprio. Era demais, uma grande imundície aos pés do muro". Para Sartre, as pinturas, quando visadas pela consciência imaginante, escapam à contingência, à existência sem sentido, ao nada: um objeto pintado não é um signo; a cor amarela do céu de Gólgota na pintura de Tintoretto não significa angústia, mas é angústia, uma angústia que não existe, mas que é ${ }^{17}$ Os objetos-imagem não têm existência, a não ser como pastas de tinta, mas têm essência. Foi assim, diante da essencialidade arrogante de um objeto, que o menino Mathieu descobriu pela primeira vez, maravilhado, sua existência livre e contingente, descobriu o nada como uma manhã, uma grande possibilidade:

O tio lhe dissera que o vaso tinha três mil anos. Mathieu aproximou-se do vaso com as mãos para trás e o contemplara com inquietude. Era apavorante ser uma bolinha de miolo de pão neste velho mundo ressequido, diante de um vaso impassível de três mil anos [...] E de repente ele retornara à mesa, erguera o vaso, que era pesadíssimo, e o jogara no chão. Isso lhe acontecera sem mais aquela e logo depois se sentira leve, diáfano. Olhara os cacos de porcelana, maravilhado. Algo acabara de ocorrer com aquele vaso de três mil anos entre os qüinquagenários, na luminosidade do verão, algo totalmente irreverente que se assemelhava a uma manhã. ${ }^{18}$

"A possibilidade própria de ser - aquela que se revela no ato nadificante - é a de ser fundamento de si como consciência pelo ato sacrificial que a 
nadifica; o para si é o em-si que se perde como em-si para se fundar como consciência". ${ }^{19}$ Nesse ato de negação, tão vivamente dado na visão das obras de arte, está posta de maneira angustiante a injustificabilidade desse ser que é tanto ausência do ser quanto fundamento de si mesmo. Essa falta de sentido, essa facticidade é "a contingência perpetuamente evanescente do em-si que persegue o para-si e o reata ao ser-em-si sem jamais se deixar agarrar" ${ }^{20}$ Ser livre é ser sempre em questão, é um ato de negação pelo para-si, um ato de existência, embora aspirando à completude da essência; e, nessa incompletude fundante, nessa aspiração ao absoluto, um ato de nadificação angustiante. $\mathrm{O}$ menino Mathieu vê sua inteira liberdade, sua injustificabilidade, sua facticidade de ser historicamente existente, "destruindo", tornando "nada" algo eterno de "três mil anos"; neste momento, os cacos brilham maravilhosos; já frente à transformação das obras de Gauguin em meras telas, Mathieu vive sua liberdade irremediável como angústia: frente à negação própria à estrutura da consciência, o homem "tem o sentimento de sua inteira gratuidade, ele se sabe como estando aí por nada, como estando demais". ${ }^{21}$ Assim o Autor nos mostra Mathieu, sentindo-se "demais, uma grande imundície aos pés do muro".

Distante daquela primeira compreensão "maravilhosa" da própria contingência, agora Mathieu gostaria de poder levar sua aluna para diante da tela onde anteriormente vira a essência da imagem, mostrar-lhe aquelas mulheres pintadas por Gauguin "que tinham sido surpreendidas quando se metamorfoseavam em coisas". Gostaria dessa "essência" para escapar à realidade burguesa, àquele "bom senso" tão francês que o tornavam apenas um "escritor de fim de semana", ridículo em comparação à coragem daquele retrato de um Gauguin "capaz de tudo". Sua existência parecia ainda mais sem sentido diante daquele projeto de vida completo, do destino necessário de Gauguin no qual todos os acontecimentos convergiam para as pinturas, diante daquele homem em imagem, essencial.

Gostara da exposição quando estava só, agora tinha a seu lado a presença física, ao mesmo tempo incômoda e atraente de Ivich. Um horror transpassa-o pela simples presença deste outro que o julga. Essa presença anterior a qualquer reflexão, ôntica, esse ser-aí. Podemos pensar que a visão realista que o acometera ao entrar essa segunda vez na exposição liga-se à vontade de "mostrar" algo à garota, deve-se a essa relação conflituosa: o "corpinho rancoroso" de Ivich, o olhar da moça perscrutando suas ações e o 
envergonhando até mesmo de seu suor de homem de trinta anos, criam uma apreensão de quem ele é, cuja aparência pouco agradável Mathieu adivinha nos atos desta outra consciência juvenil. Essa transformação do para-si em em-si, em uma imagem fixada, em objeto, é-lhe insuportável; Mathieu precisa que Ivich devolva esta parte dele mesmo: “dentro de uma hora ela estará livre e me julgará sem apelo, eu não poderei defender-me. Não é possível deixá-la partir assim, preciso explicar-lhe". ${ }^{22}$

O diálogo inquiridor entre os dois, no qual Mathieu se sente "enciumado" pela figura de Gauguin, e, ao mesmo tempo, quer confrontá-la com a sua imagem criada por Ivich, expõe o conflito entre duas liberdades, entre duas consciências em ato:

- Parece idiota, mas quero saber o que você pensa exatamente.

Ivich começou a puxar os cabelos. Era exasperante.

- Ora... nada. É uma palavra que me veio à cabeça. Mais nada.

$[\ldots]$

De repente acrescentou rapidamente, olhando para a ponta dos sapatos:

- Você está instalado e não mudaria por nada no mundo.

- Ah! era isso - disse Mathieu - Como sabe que não mudaria.

- É uma impressão, impressão de que você está com a vida organizada e com idéias acerca de tudo. Então você estende a mão para as coisas que acredita ao seu alcance, mas não daria um passo para pegá-las. ${ }^{23}$

Ivich lhe devolve sua imagem dura de francês da burguesia, com a vida organizada. Ela fixa uma faceta de Mathieu, aquela do homem de "bom senso" para quem pintar talvez fosse demais, absurdo. Na insistência com que Mathieu arranca as respostas de Ivich, nesse embate dramático entre o que olha e o que é olhado, Sartre põe em situação uma das estruturas da consciência descrita em $O$ ser e o nada: o para-si comporta, como estrutura que lhe é imanente, o para-o-outro. $\mathrm{O}$ embate entre duas consciências ativas, entre duas liberdades irredutíveis e absolutas, é sempre dialógico, dramático; e esse confronto entre alteridade/identidade, constitutivo do para-si. A estrutura conflitiva, em Sartre, evita a objetivação de uma consciência na outra, escapando das aporias da "representação", da relação irremediavelmente solipsista entre o eu e o outro das filosofias clássicas; em todas as situações, o conflito, a tensão, impedem a reificação. Mas, ao arrancar do outro minha imagem, ao procurar no outro o que não sou e o que sou para ele, neste movimento me constituo: Mathieu é, também, além de um ser livre no qual tudo está sempre em questão, o burguês 
metódico e previsível que estabelecia programas periódicos para Ivich; o "escritor de domingo".

Os projetos dos homens, suas consciências, são atravessados pela historicidade. Ser Pierre, burguês francês em 1942, ou ser Schmidt, trabalhador berlinense em 1870, essas realidades históricas das consciências põem a existência como "lançada no mundo, abandonada em "situação"". ${ }^{24}$ Este é o “em-si do para-si”, é aquela dimensão do imutável e do não escolhido, cuja facticidade injustificável compartilhamos com os outros, pois eles também vivem lançados em determinada situação. Mathieu é livre, absurdamente livre, mas é também burguês, porque está situado em um tempo histórico e em uma classe. Em oposição flagrante com a facticidade de Ivich, cuja situação era a de ser filha de "nobres russos", confrontado a esse "outro" diverso, como uma figura sobre o fundo ressalta um Mathieu francês e burguês. E, nesse confronto, também Ivich se constitui: Mathieu fixa da moça a imagem de uma eterna liberdade nobre e imaterial, quase como aquela das mulheres de Gauguin; ela pouco come, não sabe por que se importar com estudos de Biologia. Se esta imagem é constitutiva de Ivich como consciência, não é unívoca; para outra personagem, Odette, ela é apenas a menina mimada: "umas boas palmadas, disso é que precisava [...] Não come nunca, mas tenho certeza de que esconde grandes potes de geléia no quarto. Os homens são bobos demais". ${ }^{25}$

Ver é sempre "ver como" e fixar, pela alteridade, um comportamento do outro em uma imagem, ser é constituir-se como um para-o-outro, lutando contra a reificação, na trama da facticidade compartilhada pelas várias consciências e, assim, transcendente ao indivíduo. Aos atos respeitosos de Mathieu dentro do museu, ações reverentes de quem vai "à missa", Ivich opõe sua vontade nobre de possuir os quadros, de tocá-los: o olhar fixara o para-si em condutas factualmente analisadas e mostrava Mathieu qualificado, fixado depois do momento de conflito em uma "representação". Essa angústia de ser sempre olhado, essa espécie de "boa nova" às avessas é anunciada pelo anjo-pederasta Daniel em uma carta a Mathieu: somos presos às consciências alheias, somos nos olhos dos outros e também somos, em reciprocidade, responsáveis pelas imagens que fazemos das presenças a nossa volta; não há como ser indiferente, nem há repouso em aceitar tal trama de alteridade, pois não há uma essência unívoca para os pontos de vista do que sou, a não ser que recorramos à idéia de absoluto, de "deus", de eternidade: 
[...] vêem-me, logo existo. Não me cabe mais arcar com a responsabilidade do meu pastoso escoamento: quem me vê e me faz ser. Sou como ele me vê. [...] E Vós, cujo olhar me foge eternamente, suportai-me. Mathieu, que alegria, que suplício. Estou enfim transformado em mim mesmo. [...] Sou infinito e infinitamente culpado. Mas, sou, Mathieu, eu sou. Perante Deus e perante os homens, eu sou. ${ }^{26}$

Nessa trama, Mathieu é, de alguma forma, "escritor de domingo", tal como classifica Ivich. E esse tipo não aparece à toa, em oposição à fuga do mundo francês, à escolha radical de Gauguin que também fora "pintor de domingo"; ao contrário, a personagem expõe uma questão metalingüística que aponta para outra alteridade, a do escritor/leitor; aponta diretamente para o romancista Sartre, para a própria condição de confecção dos seus romances. Sartre analisa a fundo a condição burguesa dessa personagem que Ivich projeta em Mathieu: a do literato por álibi. Homens franceses, esses que são os "escritores mais burgueses do mundo", vivem a literatura como um destino já traçado nos exemplos, na tradição: "graças a esses modelos, a essas receitas, a carreira de escritor nos apareceu desde nossa infância como um ofício magnífico, mas sem surpresas, no qual se avança em parte graças ao mérito, em parte graças à antigüidade". ${ }^{27}$ Esse escritor de domingo sabe-se burguês e vive a literatura assim, como uma espécie de "higiene", "para pôr um pouco de ideal na vida", 28 para aspirar a uma (pequena que seja) aristocracia simbólica.

Esse escritor não aceita ir ao fundo, não quer ser um "destruidor", então, ataca essa outra espécie de literatura em seu próprio terreno: "você lembra Rimbaud, eu lhe devolvo Chrysale: há mais orgulho e satanismo em supor que a cadeira que se vê é uma cadeira do que em praticar o desregramento sistemático dos sentidos". ${ }^{29}$ E Mathieu, como em legítima defesa, pensa: "Gauguin perdera a dignidade humana. Aceitara perdê-la...". O desprendimento de Gauguin é oposto à tranqüilidade de Mathieu, pois o burguês se fixa em sua vida, em suas propriedades, estabelece com elas vínculos sintéticos (e poéticos). Por essa relação do homem com seu mundo tão própria ao intelectual francês, para Sartre também é burguesa a revolta surrealista, pois, ao tentar suprimir a objetividade dos objetos - como nos torrões "de açúcar" de mármore de Duchamp -, o surrealista quer suprimir também o sujeito pela escrita automática, pelo sonho. No pólo oposto ao do surrealismo, mas trabalhando com as mesmas situações de "escritor mais burguês do mundo", 
um jovem literato cita a frase lapidar para Sartre da má-fé que impregna essa condição: "é preciso fazer como todo mundo e não ser como ninguém". Espírito higienista de "escritor de domingo" para o qual é lícito "colocar a vida cotidiana entre parênteses e vivê-la minuciosamente, mas sem sujar as mãos" ${ }^{30}$ Assumir ou negar a tradição é tê-la no horizonte como constituinte da "literatura"; assumir ou negar as coisas é sabê-las ligadas ao ser burguês, atitude bem francesa que une os surrealistas aos seus adversários, diversa daquela do escritor americano, sem tradição e preso à obsessão da escrita. Esse mundo francês é o de Mathieu, sua situação histórica.

Mathieu, em outro diálogo dramático, percebe-se intimamente ligado a sua poltrona, seu apartamento, seu peso de papel de caranguejo: "'Meu peso. Para quê? Para quê?' Deixou cair o caranguejo sobre a mesa e sentenciou; 'Sou um homem liquidado"". ${ }^{31}$ Seu amigo, o ativista político Brunet, devolve-lhe uma vez mais essa imagem de homem "com a vida organizada", ao desnudar os seus vínculos com suas propriedades: "suas poltronas corrompem”, diz ao entrar no apartamento. Neste diálogo, no qual Brunet lhe oferece outra possibilidade, a do engajamento, Mathieu reconhece que fora "livre para nada" e que, por trás dessa máscara de liberdade que forjara para si, ele escolhera reiteradamente ser burguês. A isenção que temos diante do que é contingente - ser burguês, ser nobre ou trabalhador - desaparece em função de uma responsabilidade; aquela liberdade metafísica desvelada na intencionalidade da consciência diante dos quadros aparece agora como liberdade histórica diante de sua condição no mundo. Mais uma vez, Mathieu sente-se culpado, responsável. Sua consciência suspende a objetividade, "a realidade do quarto desaparecera com ele [Brunet]", ${ }^{32}$ e visa de outra forma as ruas atravessadas pelo amigo que se afasta. Por esse movimento de intencionalidade, pela nadificação própria ao para-si, Mathieu sabe que seu quarto, como uma água tranqüila e corruptora, fora escolhido em lugar das ruas às quais Brunet, afastando-se, dava realidade.

Essa liberdade absoluta do para-si, a irredutibilidade da consciência é contrária ao determinismo histórico. $\mathrm{O}$ indivíduo não pode se abandonar à história como se esta fosse um destino. Toda situação humana está vinculada a cada ação. Se Sartre anuncia, no final de $O$ ser e o nada, uma ética, ele não escreve um texto sistemático. A ética sartreana escapa à sistematização, pois, se é constituinte do para-si o ser para o outro, é parte da consciência o embate 
dramático entre os homens, configurando uma ética como exercício histórico da liberdade, passível de ser tratada apenas nas entrelinhas da forma-romance, da forma-narrativa. O romance, como forma histórica, não é a narrativa transparente de um destino trágico, um enredo e uma forma "literária" e tradicional tal qual a epopéia, mas a expressão dramática da semi-obscuridade do real, "já que o romancista tem por função primordial dar a impressão de fidelidade à experiência humana". ${ }^{33}$ "Realismo", no sentido utilizado para se falar da literatura do século XVIII em oposição à anterior, pois não se restringe a uma determinada experiência humana "superior", nem a uma forma congelada de conduta humana em um tipo, mas busca ser a mimese de toda a experiência humana. Por essa característica individualista e inovadora, podemos dizer que o romance é uma forma "burguesa". Se até mesmo os "rojões surrealistas" não escapam à condição de origem, Sartre não se exime dessa herança, ao contrário, ao falar dos escritores franceses, inclui-se entre esses homens "mais burgueses do mundo".

Mas ainda assim, se há tradição, há escolha, há a liberdade absoluta do Autor e sua relação dramática com os leitores. Sartre precisou escolher uma perspectiva de enfoque do mundo, trabalho ético por excelência. E, como para todo romancista, essa escolha perpassa a própria forma do texto: Sartre precisou escolher qual a técnica literária eficiente para seu intento. Escolher um narrador onisciente ou um foco em primeira pessoa, o discurso direto ou o indireto. Ao escolher um foco narrativo oscilante em Sursis e Com a morte na alma, e a alternância entre o discurso seco e direto e o indireto livre em A idade da razão, Sartre criou uma rede de vozes e de imagens provenientes de várias personagens, uma trama de consciências inter-constituídas pelos diálogos, pelas situações vividas; uma narrativa tramada nas singularidades de cada personagem. A categoria abstrata "História" se esvai e em seu lugar surge a temporalidade das consciências, a trama de ações cujo motor são os corpos, os homens. A Guerra não é, então, tramada apenas nos altos gabinetes, mas construída pelas personagens ao ouvirem seus rádios, ao agirem e reagirem às situações: é com isso que se faz a guerra. Como estrutura do para-si, a história é uma construção dramática e, portanto, implica a cada instante uma posição moral, uma ética. Pela escolha da forma das obras, a negação da realidade pela literatura não precisa ser um "álibi", essa negatividade pode pôr outro mundo em palavras e expor, pela ficção, a prerrogativa conflituosa e ética da condição humana: 
Uma mancha de luz ornava de vermelho a orelha do tipógrafo: o lóbulo parecia um morango sanguinolento: "É com isso que se faz a guerra", pensou Mathieu. Até então ela lhe aparecera sob a forma de um emaranhado de aço retorcido, vigas partidas, ferro e pedra. Agora o sangue tremia aos raios do sol, uma claridade ruiva invadira o vagão: a guerra era um destino de sangue; seria feita com o sangue daqueles seis homens, com o sangue que se estagnava no lóbulo de sua orelha, com o sangue que corria sob sua pele, com o sangue de seus lábios. ${ }^{34}$

\section{Referências}

SARTRE, J-P. A náusea. 9. ed. Rio de Janeiro: Nova Fronteira, s/d.

SARTRE, J-P. A idade da razão. 2. ed. São Paulo: Difusão Européia do Livro, 1959.

SARTRE, J-P. Com a morte na alma. São Paulo: Difusão Européia do Livro, 1958.

SARTRE, J-P. Sursis. São Paulo: Difusão Européia do Livro, 1958.

SARTRE, J-P. L'Être et le Néant, essai d'ontologie phénoménologique. Paris:

Gallimard, 1943.

SARTRE, J-P. A imaginação: Sartre/Heidegger. São Paulo: Abril, 1973.

SARTRE, J-P. O que é literatura? São Paulo: Ática, 1989.

BLANCHOT, M. Os romances de Sartre. In: A parte do fogo. Rio de Janeiro: Rocco, 1997.

WATT, I. A ascensão do romance. São Paulo: Companhia das Letras, 1990. 